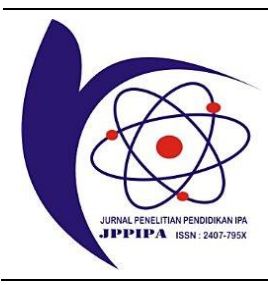

\title{
Application of the Science Technology Society (STS) Model to Craft and Entrepreneurship Materials to Develop Soft Skills of Students
}

\author{
Fira Roswita ${ }^{1}$, Sulastri2 ${ }^{*}$, Ibnu Khaldun ${ }^{2}$ \\ ${ }^{1}$ Program studi Pendidikan IPA Program Pascasarjana Universitas Syiah Kuala, Banda Aceh, Indonesia \\ ${ }^{2}$ Program Studi Kimia, FKIP, Universitas Syiah Kuala, Banda Aceh, Indonesia
}

DOI: $\underline{10.29303 / j p p i p a . v 7 i 1.525}$

\section{Article Info}

Received : Nopember 26th 2020

Revised : December 30th 2020

Accepted: January $4^{\text {th }}, 2021$

\begin{abstract}
The development of information technology requires students to have life skills when they enter workplaces. Soft skills are one of the skills that students must have. This research aims to analyze the application of the science technology society (STS) model to develop their soft skills. The method used in this research is a pre-experimental design with a one-shot case study design. The population was the students of class XI MIA with simple random sampling used as the sampling technique, and the research subjects were thirty-two (32) students of class XI MIA 2 that were divided into six groups. The results showed that the application of STS-based student worksheets could develop their soft skills about $88.15 \%$, categorized as very good, and had high qualifications.
\end{abstract}

Keywords: student worksheet; STS, soft skill; plant-based; and animal-based food processing

Citation: Roswita, F., Sulastri, S., \& Khaldun, I. (2021). Application of the Science Technology Society (STS) Model to Craft and Entrepreneurship Materials to Develop Soft Skills of Students. Jurnal Penelitian Pendidikan IPA, 7(1), 67-73. doi:https://doi.org/10.29303/jppipa.v7i1.525

\section{Introduction}

The 2013 curriculum directs students to become qualified human beings who are capable and proactive in responding to the challenges of the ever-changing times. Learning in the 2013 curriculum is multidisciplinary learning, by integrating several sciences in the process. Craft and entrepreneurship lesson a is one of the local content subjects in the 2013 curriculum. This subject aims to make students able to carry out creative economic activities, besides that they can take advantage of the potential of local community wisdom so that they can create jobs for themselves and others (Anggraini, 2015), and being able to foster an entrepreneurial spirit in students, is also one of the government's efforts to prepare more entrepreneurs in Indonesia (Darmiyati et al., 2017).

Craft and entrepreneurship is also a lesson that provides knowledge, attitudes, and skills for students to be able to develop life skills based on technology, economics, and art as well as train the ability to express ideas and ideas and creativity. The results of observations and needs analysis that has been carried out at Senior High School 2 Bireuen shows that students seem less interested in taking part in learning and are less able to apply the knowledge learned into their lives. Other results obtained that the lack of teaching materials in the form of student worksheets that can support students to be more active in craft and entrepreneurship lesson, so it was not easy for the students to develop life skills in the classes.

Craft and entrepreneurship learning is expected to generate enthusiasm for learning science. Science has an important role in preparing students to enter the world of work where science underlies technological development, while technology supports the development of science (Gusfarenia, 2013). These skills are in the form of interpersonal, 
intrapersonal, and creativity skills. Efforts to develop interpersonal skills (soft skills) such as communication skills, cooperation, responsibility, self-confidence, and problem-solving skills are needed so that students enter the world of work more easily (Robles, 2012; Agarwal and Ahuja, 2014). 75\% success in a career is determined by soft skills while $25 \%$ is determined by hard skills, besides that soft skills also refer to various skills, knowledge, and life values that are basic personal, warmth, and high optimism (Rashidi et al., 2013).

One of the successes of students can be realized by integrating several sciences. One approach that is integrated with learning is the science technology society (STS). The STS approach can also express the ideas that students have in identifying, analyzing, and finding solutions to issues or problems faced in everyday life (Sengdala and Yuenyong, 2014). In addition, STS can also hone the skills of students to explore how science and technology can contribute to people's lives and direct them to be able to develop their skills (Chawdhury, 2016; Bettencourt et al., 2011). STS is an approach that links science, technology, and its benefits to society (Budiarti and Suprihatin, 2017).

Research that has been conducted using the STS approach has shown positive results. Some of them are the increase in the minimum completeness value to $85 \%$ in acidic material (Junita et al., 2016), through the application of the STS approach learning effectively increases students' high-level thinking skills by $95 \%$ (Marwah et al., 2017) ), there was an increase in learning outcomes by $85 \%$ by applying the STS-based learning model (Lestari et al., 2016). Learning with the STS approach to increase students 'awareness of the environment has increased by $78.2 \%$ for knowledge, while $77.8 \%$ for students' understanding (Junita et al., 2016).

The application of the STS learning model can facilitate the dimensions of attitudes, processes, products, applications, and creativity with the aim that science concepts can be applied through skills that are beneficial to students and society (Annisa and Rohaeti, 2017). Abas 'research (2012) shows that STS learning is also effective in improving students' mastery of concepts.

The material developed in this study is student worksheets which were designed to follow the STS stages by raising issues or problems that are often found in the community, namely how to process manga into fruit leather, namely fruit snacks which are processed food in the form of thin sheets that have a distinctive consistency and taste and can be used for processing. commercial on an industrial scale (Rosalina et al., 2013), processing orange peels into sweets, namely the use of orange peel waste as a raw material for making sweets (Yustinah and Feranandara, 2016), and processing tuna into wood fish processing, this processing is intended to increase the storage capacity of fish as an animal source so that it does not decompose due to the activity of microorganisms (Marine et al., 2015). This study uses the STS approach by collaborating the principles of science, technology, and society. So the student worksheets were designed to see the soft skills development of students.

Based on the background of the problem, research has been carried out with regard to the application of the Science Technology, Society (STS) model to Craft and Entrepreneurship Materials to Develop Soft Skills for Students at Senior High School 2 Bireuen.

\section{Method}

This study uses a quantitative approach and focuses on the application of STS with the aim of developing soft skills on craft and entrepreneurship material at Senior High School 2 Bireuen. The independent variable in this study is STS learning, while the dependent variable is the soft skill development of students. The method used in this research is a pre-experimental design with a one-shot case study design. The research was conducted at Senior High School 2 Bireuen. The population in this study were all students of class XI MIA at Senior High School 2 Bireuen in the 2019/2020 school year. The sample selection is done by simple random sampling. The instruments in this study were 1) Student and Teacher Need Analysis Sheet, 2) The Quality Assessment Form for Student Worksheets, 3) Student's Soft Skill Observation Sheet, 4) Form of Test Result Assesment for Student Worksheets and 5) Appearance and Taste Assessment Sheet Product. The research data is the data obtained from the percentage of the application of student worksheets and the development of entrepreneurial soft skills of students. The assessment of the application of the student worksheets were obtained based on the recapitulation of the results of the student worksheets, and the assessment of the entrepreneurial soft skills of students was obtained from the observations conducted by filling in a checklist $(\sqrt{ })$ on the observation sheet, then analyzed the quantitative descriptive percentage calculation. The criteria for assessing the application of craft and entrepreneurship and observations of students' soft skills in entrepreneurship are expressed as a percentage calculated by the total score obtained (student answer scores) divided by the maximum number of scores and 
multiplied by one hundred percent (Susanto et al., 2012). The calculation results are classified into three eligibility assessment criteria, namely high (85-100), moderate (84-66), and low (65-0) (Riduwan, 2012).

\section{Result and Discussion}

The student worksheets that had been completed first were assessed by 4 experts. The results of the assessment obtained the percentage of the results of the student worksheets quality assessment for the material aspects, learning components, presentation, language, physical appearance, and illustrations respectively 91.25, 97.50, 97.50, 95.00, 99.17, and 95, 00. The average result of the student worksheets quality assessment assessed by experts from the five aspects were $95.90 \%$ categorized as very good. This is in accordance with the description of the student worksheets feasibility score by Arikunto (2013) which states that the acquisition of values in the range of $81-100 \%$ is in the very good category. Thus, the developed student worksheets can be used in trials.

1. Implementation and Trial of STS-based student worksheets

The revised student worksheets based on the development stages is then applied to students. The implementation was limited to two meetings at Senior High School 2 Bireuen. The stages of implementing student worksheets are divided into 3, namely the preliminary stage, the core activity stage, and the closing activity stage.

The topic in STS-based student worksheets is a problem that students often find in their daily life. Each group was given different problems, namely groups I and II regarding the manufacture of mangoes as fruit leather, Groups III and IV concerning the processing of orange peels as sweets, while groups V and VI were concerned with processing tuna as wood fish. see the final quality of the product produced. In the early stages of learning, students were given an apperception in the form of a question "You must have often heard the phrase typical regional food. What is meant by regional specialties? What are the regional specialties in Bireuen? " and motivation related to the application of chemistry in life, such as "In everyday life, humans need food and drink for the process of growth and development of the body. Currently, various types of food and drinks can be served in various forms. How do we process these foodstuffs such as plant and animal food so that they have high selling power? " (with, showing pictures to students).

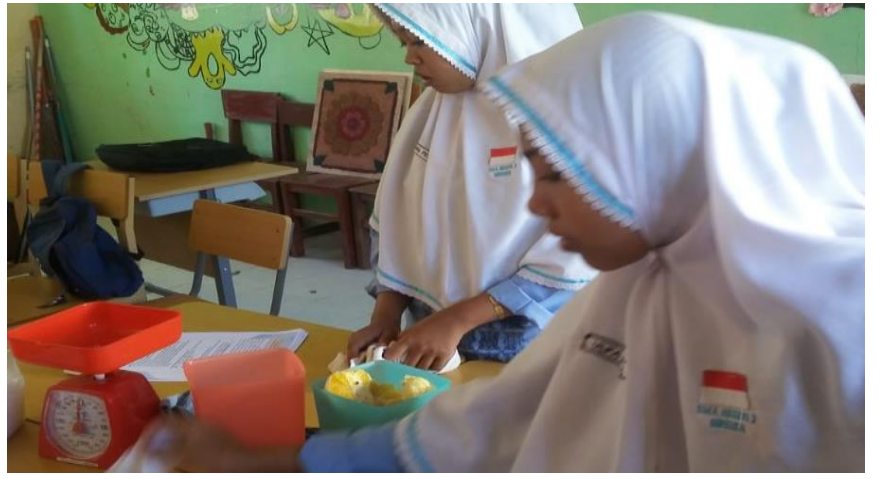

Figure 1. Student activities Using STS-Based Student Worksheets.

The next stage is followed by core activities using STS-based student worksheets with the following stages: (1) initiation stage, at this stage, students observe the problems or phenomena presented in the student worksheets. Then students discuss to make problem formulations and hypotheses based on the given phenomena. At this stage, students are guided by the teacher to be able to formulate problems and hypotheses on these problems. (2) In the concept formation stage, at this stage, students find answers to problem formulations by conducting experiments. Students are very enthusiastic and full of enthusiasm in following this stage. They help each other in processing food for cleaning, cutting, boiling, and also doing other work. Experiments are carried out to collect as much information as possible so that it becomes new findings for students. Furthermore, students process data from the information obtained and write it down in the observation table. Complete the task under the guidance of the teacher. (3) In the concept application stage, at this stage, students are given the task to identify at least three benefits of each raw material in everyday life. Students are given the opportunity to seek answers from various sources and literature. Students begin to think, give each other opinions, and write down answers to these tasks (4) The stage of conceptualization, at this stage students re-analyze the processing of data and information obtained and the hypotheses that have been formulated then check again, whether they are in accordance with the results that have been obtained and then conclusions are made based on the learning that has been done. (5) The evaluation stage is the final stage carried out as a form of assessment of learning outcomes. At this stage, students present the results of group work by displaying the final product that has been made. The learning stages with the STS approach require students to be actively involved in learning. These activities train students' sensitivity to the environment as a result of the development of science and technology (Abas, 2012). In the final stage, students together conclude the 
learning material with teacher guidance and reflect on learning.

Activities carried out by students are observed and students are measured using observation sheets. Observations were made during the experiment by looking at the interactions of students during the learning process. 3 observers are students of the Master of Science Education Study Program. The results of the STS-based student worksheets assessment that have been applied to students are presented in Table 1.

Table 1. Results of the STS-based student worksheets trial assessment used by students

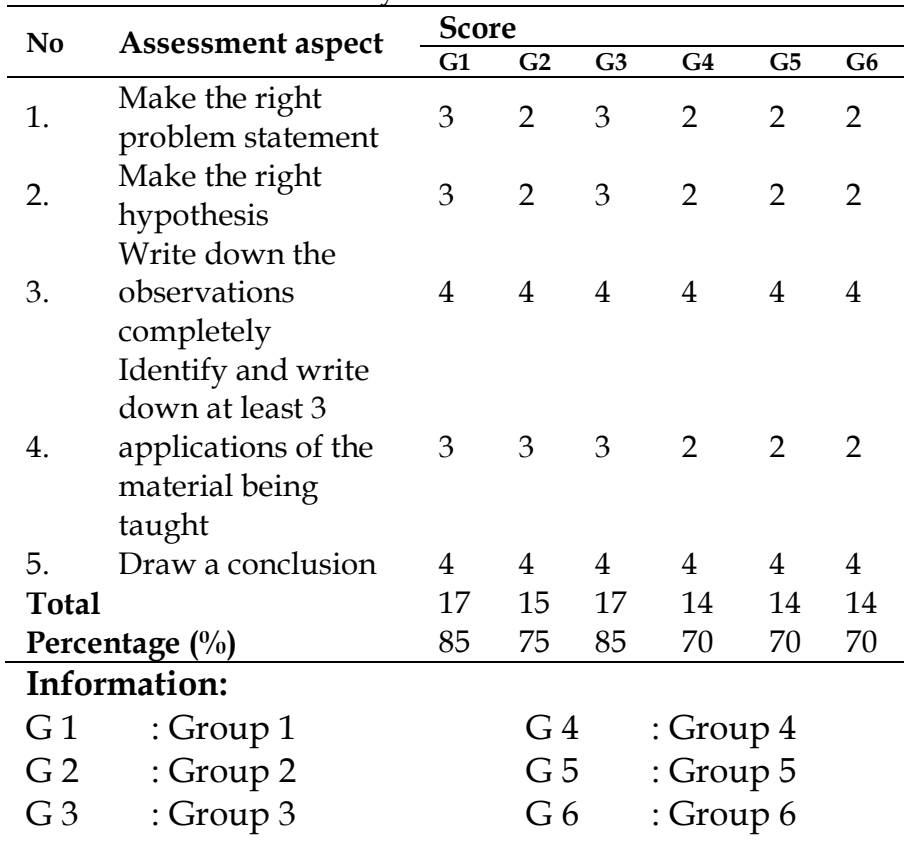

Based on the values contained in table 1, the highest score is in the aspect of writing down the observations completely and drawing conclusions. This is evidenced by where students are active in conducting experiments and discussing to make observations. If students are active in learning, students will have more control over the learning material (Sidi and Sudrajat, 2014). It also encourages students to explain natural phenomena and try to use science and technology to solve problems in society.

The lowest score on the aspect of formulating the problem and making hypotheses. This shows that students have understood the work being done so that they can write down their observations and be able to draw conclusions from the overall learning. Then it can be concluded that the STS-based student worksheets that has been developed can be recommended to be applied in craft and entrepreneurship learning in schools. This is in line with the findings of Dini et al. (2013) showed that there was a significant difference in the effectiveness test of students' cognitive abilities before and after using STS-based student worksheets. So that
STS-based student worksheets is effective for use in learning. The use of STS-based teaching materials can also improve learning outcomes and student interest in learning science at all levels of education (Akcay and Akcay, 2015).

\section{Student Soft Skill Assessment}

The soft skill assessment of students is carried out during the practicum of making food from vegetable and animal ingredients. The practicum was carried out in accordance with the student worksheets that had been distributed to each group. There are nine indicators of soft skills that are assessed for each student. The maximum and minimum scores for each indicator are 4 and 1 respectively according to the scoring rubric in the attachment. The results of the soft skill assessment of students are presented in Figure 2.

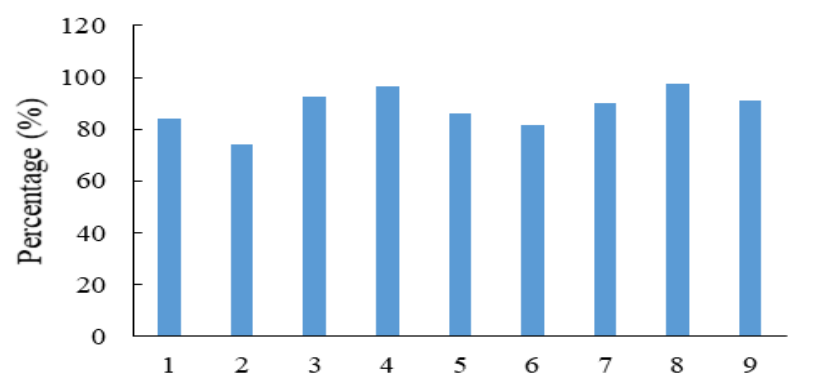

Figure 2. Percentage of Students' Soft Skills Assessment.

$1=$ Communication

$2=$ Politeness

$3=$ Flexibility

$4=$ Integrity

$5=$ Interpersonal skills

$6=$ Professionalism

$7=$ Responsibility

8 = Teamwork

$9=$ Work ethic

Based on Figure 2, overall the results of the observation of soft skills of students are classified as high qualifications, namely $88.15 \%$, this shows that the overall soft skills of students are very good so that soft skills develop students are expected to continue to train them. Soft skills play a big role in one's career such as social interaction skills in society. These skills are also highly sought after by employers who are recruiting new graduates. The results of Seetha's (2014) research show that communication skills are $28 \%$, good behavior $24 \%$, and the ability to work together by $17 \%$ are the highest skills in soft skill attributes. Therefore, it is very important to describe the fulfillment of the gap between providers and entrepreneurs so that students are sufficiently prepared to acquire the soft skills needed by stakeholders. In other words, teachers need to take advantage of more effective teaching methods: 
to better assist students for their future jobs and in serving demands while in the world of work (Yager et al., 2009).

\section{Assessment of Students' Food Products}

Products that have been made by students are assessed by the teacher with the aspect of assessment being appearance, taste, and cleanliness. The results of the assessments that have been carried out are presented in Table 2.

Table 2. Results of the assessment of food products

\begin{tabular}{|c|c|c|c|c|c|c|c|c|c|}
\hline \multirow{2}{*}{ No } & \multirow{2}{*}{ Assessment Aspects } & \multicolumn{6}{|c|}{ Score } & \multirow{2}{*}{ Total } & \multirow{2}{*}{$\%$} \\
\hline & & G1 & G2 & G3 & G4 & G5 & G6 & & \\
\hline 1. & Appearance & 4 & 4 & 4 & 4 & 4 & 4 & 24 & 100 \\
\hline 2. & Taste & 4 & 4 & 4 & 4 & 4 & 4 & 24 & 100 \\
\hline 3. & Cleanliness & 4 & 4 & 4 & 4 & 4 & 4 & 24 & 100 \\
\hline
\end{tabular}

Based on Table 2 clearly shows that each group has done its job perfectly and the score for each aspect of the assessment is $100 \%$ in the very good category. The assessment of the food products that have been produced is each group doing it with different work steps. Three kinds of food are processed, namely processing mangoes into fruit leather, orange peels into candied orange peels, and tuna fish into wooden ties. All of this work is carried out to convert raw materials that initially have a low selling value to a higher one.

The processing of mangoes into fruit leather was carried out by groups one and two. The difference between these two groups in processing food is the materials they use. Group one used mangoes, sugar, glucose, citric acid, and modified parchment paper (Yusmita and Wijayanti, 2018), while group two used mangoes, water, citric acid, gum arabic, sorbitol modified from Praseptiangga et al (2016). Then the processing of orange peels into candied orange peels was carried out by groups three and four, similarly to processing mangoes into fruit leather, the difference in this processing also lies in the use of the ingredients. Group three uses ingredients in the form of orange peel, granulated sugar, salt, lime juice, orange peel, lemon juice, and vanilla (Sagala et al., (2017). Group four uses ingredients in the form of orange peel, sucrose, salt, water and lime (Siregar). et al., 2016) Furthermore, the processing of tuna fish into wooden ties is carried out by groups of five and 6 . These two groups each use tuna and skipjack fish which follow the work steps of (Sulaiman, 2014; Bakri and Nasir, 2018).

The products produced by all groups in terms of appearance include interesting aspects in presenting/design, layout, color combinations, and appearance of materials, from the aspect of taste, have provided the appropriate color, aroma, sweet/salty level, and texture. And from the aspect of cleanliness, all groups showed a neat, clean, attractive, and creative presentation in their packaging. Based on the results of data analysis, it shows that students have been able to master the concept formation stage contained in the student worksheets according to the stages of the STS model. Mastery of these technological aspects is in the form of processing and packaging techniques for foodstuffs with their creative abilities. The results of products that have been completed by students as a result of packaging creativity can be seen in Figure 3.

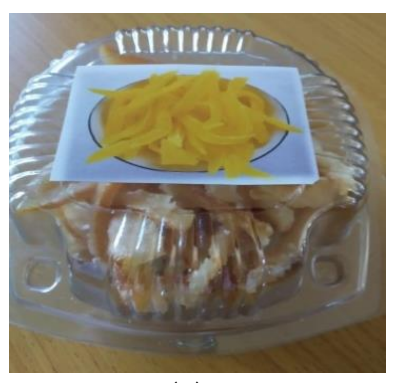

(1)

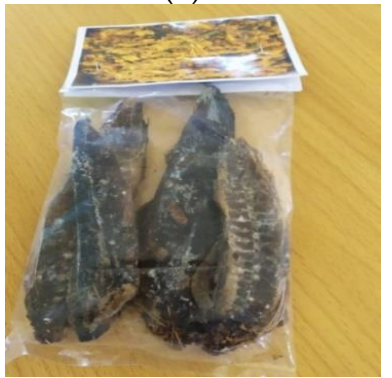

(3)

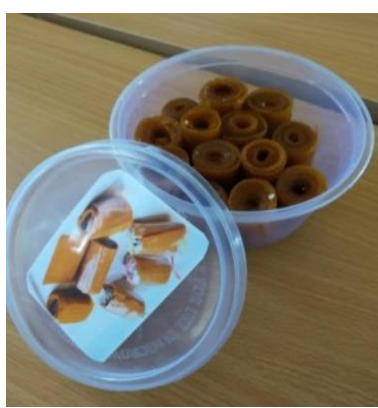

(5)

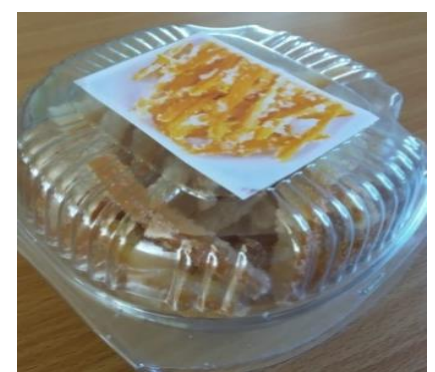

(2)

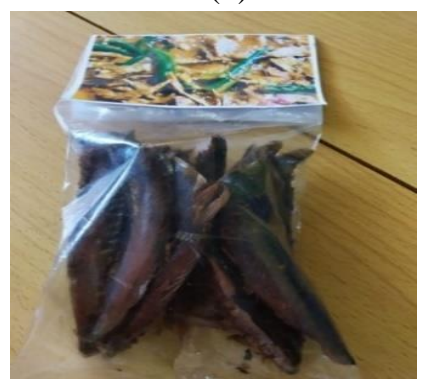

(4)



(6)
Figure 2 The results of student creativity in craft and entrepreneurship learning using STS-based student worksheets: (a) group 1, (b) group 2, (c) group 3, (d) group 4, (e) group 5, and (f) group 6. 


\section{Conclusion}

Based on the results of research and data analysis, it can be concluded that the application of STS-based student worksheets in craft and entrepreneurship learning can develop the soft skills of students by $88.15 \%$ with very good categories also have high qualifications. Positive responses were obtained from students of $84.53 \%$ with good categories for the application of the STS learning model in developing soft skills in craft and entrepreneurship learning.

\section{References}

Abas. (2012). Perbandingan Hasil Belajar Model Cooperative Learning dengan Model Science Technology Society Pada Siswa Kelas X MAN 1 model kota Bengkulu. Jurnal Exacta, 9(1):11-16.

Agarwal, N., dan Ahuja, V. (2014). Preliminary exploration of significance of soft skills in groups with specific reference to peer-assessment. Journal of Management Policies and Practices, 2(2):85-97.

Akcay, B., \& Akcay, H. (2015). Effectiveness of ScienceTechnology-Society (STS) Instruction on Student Understanding of the Nature of Science and Attitudes toward Science. International Journal of Education in Mathematics, Science and Technology, 3(1), 37. https://doi.org/10.18404/ijemst.50889

Anggraini, A., \& Sukardi, S. (2015). Pengembangan Modul Prakarya Dan Kewirausahaan Materi Pengolahan Berbasis Product Oriented Bagi Peserta Didik SMK Jurnal Pendidikan Vokasi, 5(3), 287. https://doi.org/10.21831/jpv.v5i3.6484

Annisa, \& Rohaeti, E. (2017). Pengaruh model pembelajaran STM terhadap kemampuan berpikir kritis dan sikap peduli lingkungan. Jurnal Pendidikan Matematika dan Sains, 4(2):98105. : http://journal.uny.ac.id/index.php/jpms

Arikunto, S. (2013). Dasar-Dasar Evaluasi Pendidikan. Jakarta: Bumi Aksara.

Bakri, M., \& Nasir. (2018). Manajemen Usaha Pengolahan Ikan Kayu (Keumamah) Masyarakat Lampulo Banda Aceh. Serambi Akademica, VI (2)18.

Bettencourt, C., Velho, J.L. dan Almeida, P.A (2011). Biology teachers' perceptions about ScienceTechnology-Society (STS) education. , 15(none), 3148

3152. http://doi:10.1016/j.sbspro.2011.04.262

Budiarti,Y. \& Suprihatin, S. (2017). Pengaruh model pembelajaran sain teknologi masyarakat (STM) terhadap kemampuan soft skill mahasiswa. Jurnal Pendidikan Ekonomi UM Metro, 5(2):131-144
Chawdhury, M.A. (2016). The Integration of science technology society/science technology society environment and socio scientific issues for effective science education and science teaching. Electronic Journal of Science Education, 20(5):1938.

Darmiyati., Sudjarwo., \& Pujiati. (2017). Pengembangan Modul Prakarya dan Kewirausahaan Berorientasi Pembelajaran Konstektual untuk Siswa SMA. Tesis tidak dipublikasi. Lampung: Universitas Lampung.

Dini, W.S., Asrul., \& Dwiridal, L. (2013). Pengembangan LKS berbasis sains teknologi masyarakat padakonsep kalor dan prinsip konservasi energi untuk pembelajaran siswa kelas Xsemester 2 SMAN 4 Pariaman. Pilar of Physics Education. 1(2):97-104. doi: http://dx.doi.org/10.24036/735171074

Gusfarenia, D. (2013). Model pembelajaran sains teknologi masyarakat (STM). Jurnal Edu-Bio, 4:2131.

Junita, S., \& Halim, A. (2016). Penerapan Pendekatan Sains Teknologi Masyarakat (STM) Untuk Meningkatkan Kesadaran Siswa Terhadap Lingkungan Pada Pembelajaran Kimia Materi Asam Basa. Jurnal Pendidikan Sains Indonesia, 4(1), 122972. https:// doi.org/10.24815/jpsi.v4i1.6590

Lestari, H., Ayub, S., \& Hikmawati, H. (2017). Penerapan Model Pembelajaran Sains Teknologi Masyarakat (STM) untuk Meningkatkan Hasil Belajar Fisika Siswa Kelas VIII SMPN 3 Mataram. Jurnal Pendidikan Fisika dan Teknologi, 2(3), 111115. doi:http://dx.doi.org/10.29303/ipft.v2i3.297 Marine, S.S., Sayeed, Md. A., Barman, P.P., Begum, R., Hossain, Md.M., \& Alam, M.D. (2015). Traditional methods of fish drying: An explorative study in Sylhet, Bangladesh. International Journal of Fishery Science and Aquaculture, 2(1), 28-35.

Marwah, D., Wahyudin, D., \& Cynthia, R. (2017). Efektivitas penerapan model pembelajaran science technology and society (STS) terhadap peningkatan kemampuan berpikir tingkat tinggi (studi kuasi eksperimen pada mata pelajaran IPA terhadap siswa kelas VII SMPN 26 kota Bandung) EDUTECHNOLOGIA, 3 (3):71-182.

Praseptiangga, D., Aviany, T., \& Parnanto, N. (2016). Pengaruh Penambahan Gum Arab terhadap Karakteristik Fisikokimia dan Sensoris Fruit Leather Nangka (Artocarpus heterophyllus). Jurnal Teknologi Hasil Pertanian, 9(1). doi:http://dx.doi.org/10.20961/jthp.v9i2.12858

Rashidi, a., Fakhrul Adabi, a. K., \& Ilhamie, a. G. a. (2013). Integrating soft skills assessment through soft skills workshop program for engineering students at University of Pahang: An analysis. 
International Journal of Research In Social Sciences, 2(1), 33-46.

Riduwan. (2012). Belajar Mudah Penelitian Untuk GuruKaryawan dan Peneliti Pemula. Bandung: Alfabeta.

Robles, M. M. (2012). Executive Perceptions of the Top 10 Soft Skills Needed in Today's Workplace. Business Communication Quarterly, 75(4), 453465. doi:10.1177/1080569912460400

Rosalina, Y., Susanti, L., \& Sulasmi, T. (2013). Studi Pengolahan Fruit Leather Mangga Varietas Bengkulu (Mangifera indica L.). Jurnal Agroindustri, 3(2): 124-132. doi: https://doi.org/10.31186/j.agroindustri.3.2.124$\underline{132}$

Seetha, N. (2014). Are Soft skills Important in the Workplace? â $\square$ A Preliminary Investigation in Malaysia. International Journal of Academic Research in Business and Social Sciences, 4(4), 4456. https://doi.org/10.6007/ijarbss/v4-i4/751

Sengdala, P. \& Yuenyong, C. (2014). Enhancing Laos students' understanding of the nature of science in physics learning about atom for peace. European. Journal of Science and Mathematics Education, 2(2):119-126.

Sidi, P., \& Sudrajat, A. (2014). Pembelajaran model STS berbantuan media untuk meningkatkan aktivitas, sikap, dan hasil belajar IPS. Jurnal Harmoni Sosial, 1(2):179189. https://doi.org/10.21831/hsjpi.v1i2.2439

Siregar, G., Setyohadi, \& Ridwansyah. (2016). Pengaruh Lama Fermentasi dan Konsentrasi Gula Terhadap Mutu Manisan Semangka. Jurnal Rekayasa Pangan dan Pertanian, 4(2): 194-198.

Sulaiman, I. (2014). Perbandingan Metode Pengeringan Dan Jenis Ikan Pada Pengujian Organoleptik Ikan Kayu Khas Aceh (Keumamah). Jurnal Agroindustri, 4(1): 40-47.

Susanto, A., Raharjo., Prastiwi, S. \& Muji. (2012). Permainan monopoli sebagai media pembelajaran sub materi sel pada siswa SMA kelas XI IPA. Jurnal Bioedu, 1(1):1-6.

Yager, R.E., \& Akcay, H. (2008). Comparison of Student Learning Outcomes in Middle School Science Classes with an STS Approach and a Typical Textbook Dominated Approach. RMLE Online. 31(7): 1-16. doi: $10.1080 / 19404476.2008 .11462050$

Yusmita, L., \& Wijayanti, R. (2018). Pengaruh penambahan jerami Nangka (Artocarpus Lam) terhadap karakteristik fruit leather manga (Mangifera indica L). Jurnal Teknologi dan Industri Pertanian Indonesia, 10(1):37-41. https://doi.org/10.17969/jtipi.v10i1.10152

Yustinah, \& Fanandara, D. (2016). Ekstraksi Minyak Atsiri Dari Kulit Jeruk Sebagai Bahan Tambahan
Padapembuatan Sabun. Konversi, 5 (1): 25-30. doi: https://doi.org/10.24853/konversi.5.1.25-30 